\title{
The Holocene thermal maximum in the Nordic Seas: the impact of Greenland Ice Sheet melt and other forcings in a coupled atmosphere-sea-ice-ocean model
}

\author{
M. Blaschek and H. Renssen \\ Cluster Earth \& Climate, Faculty of Earth and Life Sciences, VU University Amsterdam, De Boelelaan 1085, \\ 1081HV Amsterdam, The Netherlands \\ Correspondence to: M. Blaschek (m.blaschek@vu.nl)
}

Received: 3 October 2012 - Published in Clim. Past Discuss.: 26 October 2012

Revised: 6 June 2013 - Accepted: 28 June 2013 - Published: 29 July 2013

\begin{abstract}
The relatively warm early Holocene climate in the Nordic Seas, known as the Holocene thermal maximum (HTM), is often associated with an orbitally forced summer insolation maximum at $10 \mathrm{ka} \mathrm{BP}$. The spatial and temporal response recorded in proxy data in the North Atlantic and the Nordic Seas reveals a complex interaction of mechanisms active in the HTM. Previous studies have investigated the impact of the Laurentide Ice Sheet (LIS), as a remnant from the previous glacial period, altering climate conditions with a continuous supply of melt water to the Labrador Sea and adjacent seas and with a downwind cooling effect from the remnant LIS. In our present work we extend this approach by investigating the impact of the Greenland Ice Sheet (GIS) on the early Holocene climate and the HTM. Reconstructions suggest melt rates of $13 \mathrm{mSv}$ for $9 \mathrm{kaBP}$, which result in our model in an ocean surface cooling of up to $2 \mathrm{~K}$ near Greenland. Reconstructed summer SST gradients agree best with our simulation including GIS melt, confirming that the impact of the early Holocene GIS is crucial for understanding the HTM characteristics in the Nordic Seas area. This implies that modern and near-future GIS melt can be expected to play an active role in the climate system in the centuries to come.
\end{abstract}

\section{Introduction}

In the early Holocene a period of relatively warm climate, the Holocene thermal maximum (HTM), has been associated with the orbitally forced Northern Hemisphere summer insolation maximum at approximately $10 \mathrm{kaBP}$ (Jansen et al., 2008). Indeed, detailed analyses of proxy data and model results have confirmed that orbital forcing is the dominant long-term forcing considering temperature response at the scale of the Arctic (Renssen et al., 2009). Compared to this impact of orbital forcing, the effect of variations in atmospheric greenhouse gases on the temperature response is relatively small (Renssen et al., 2009). Although the HTM is mainly orbitally forced, the spatial and temporal response of the climate system is diverse. Maximum temperatures were often delayed by several thousand years compared to the summer insolation maximum, as evidenced by numerous terrestrial and marine proxy records (e.g. Jansen et al., 2007). The causes of this spatial and temporal complexity of the HTM have not been resolved for all regions, for instance the Nordic Seas. This region is the transition zone of two major ocean currents: the North Atlantic Current (NAC) to the east, transporting warm and saline waters to the north, and the East Greenland Current (EGC) to the west, transporting cool and less saline waters to the south. In this paper we evaluate the characteristics of the HTM in this important region by analysing the impact of potential forcing factors in numerical climate model simulations and by comparisons with available proxy evidence.

In a previous study, Renssen et al. (2009) have shown in transient climate model simulations, combined with summer temperature reconstructions based on terrestrial proxies, that the Laurentide Ice Sheet (LIS) delayed the HTM over the North Atlantic and downwind continents (Europe and Asia) by up to $3000 \mathrm{yr}$. This ice sheet persisted until 
around $6 \mathrm{ka} \mathrm{BP}$ and caused regional cooling by inducing melt water discharges and by altering the surface albedo and topography. An important effect of the LIS melt flux was that it suppressed deep convection in the Labrador Sea, causing expanded sea ice cover and cooler surface conditions compared to today. An important part of this spatio-temporal complexity can be explained by the impact of the remnant LIS in North America (Kaufman et al., 2004; Kaplan and Wolfe, 2006). However, the simulated characteristics of the HTM of Renssen et al. (2009) were not specifically compared to reconstructions of sea surface conditions so that it remained unclear what the impact of the LIS was on modelled Holocene sea surface temperatures (SSTs) in the North Atlantic Ocean and the Nordic Seas, and if the model results were consistent with marine proxies from this region.

The characteristics of the HTM (timing and magnitude) in the Nordic Seas are rather unclear, as different marine proxies suggest different SST evolutions during the Holocene. Sea surface reconstructions based on diatoms show a nonuniform response of SSTs in the eastern and western parts of the Nordic Seas over the last $10000 \mathrm{yr}$ (Andersen et al., 2004). These diatom-based reconstructions indicate that over the Vøring Plateau (in the east), maximum warming occurred between 10 and $9 \mathrm{kaBP}$, with summer SSTs being $4-5 \mathrm{~K}$ above the pre-industrial mean, while on the western side the thermal maximum was later (between 8.5 and $6.5 \mathrm{kaBP}$ ) and less expressed ( $1 \mathrm{~K}$ above the pre-industrial mean). Consequently, SSTs based on diatoms show an earlier (by 1.5$2.5 \mathrm{ka}$ ) and warmer HTM (3-4 K difference) on the eastern than on the western side. This east-west contrast has been explained by a stronger cooling impact by postglacial sea ice and melt water in the west before $8.5 \mathrm{ka} \mathrm{BP}$, leading to a clearer expression of the early Holocene warming influence by insolation in the east (Andersen et al., 2004). However, it has been argued by Koç et al. (1993) and other studies (Kaufman et al., 2004; Jansen et al., 2008; Risebrobakken et al., 2011) that these warmer temperatures cannot be due to insolation alone. Eastern SSTs reconstructed from alkenones (Calvo et al., 2002) show a behaviour similar to the orbital trend, but are considerably lower at the thermal maximum (by 2-3 K) and yield a later HTM (i.e. between 8.5 and $5.5 \mathrm{ka} \mathrm{BP})$ at the Vøring Plateau. Moreover, at the same site, SST reconstructions based on foraminifera and radiolarians also lack this early HTM suggested by diatoms (Risebrobakken et al., 2003, 2011; Cortese et al., 2005; Dolven et al., 2002). Jansen et al. (2008) suggest that the SST maximum recorded in proxy data above the seasonal thermocline (diatoms, alkenones) is forced by the summer insolation maximum and that deeper dwelling species (foraminifera and radiolarians) are not influenced. Andersson et al. (2010) support this hypothesis in a comparison with climate model simulations of the $6 \mathrm{ka} \mathrm{BP}$ climate performed with the CCSM3 model. These model results suggest that seasonal summer warming, related to the orbitally forced summer insolation maximum, is restricted to the upper $30 \mathrm{~m}$ in the Nordic Seas during the early Holocene. Recently, Risebrobakken et al. (2011) separated the impact of orbitally forced summer insolation and early Holocene warm surface waters associated with increased advection of Atlantic waters (Kaufman et al., 2004; Koç et al., 1993) and emphasized the effect of both horizontal heat advection and radiative forcing on overall conditions in the Nordic Seas. The non-uniform response across the Nordic Seas as reconstructed by Andersen et al. (2004) seems to be a robust feature in palaeoceanographic reconstructions, thus raising the question of the origin of this zonal difference. Consequently, the expression of the HTM in the Nordic Seas and the impact of possible feedbacks like increased heat advection by the NAC or Greenland melt water are still unclear.

In principle, climate model simulations could shed light on the role of different forcings and the SST response during the Holocene in the Nordic Seas. The model results of Renssen et al. (2009) suggest an earlier (8-7 ka BP) and warmer (more than $2 \mathrm{~K}$ above pre-industrial level) thermal maximum in the western part of the Nordic Seas than in the eastern part (7-6 ka BP and up to $1 \mathrm{~K}$ above pre-industrial level). Hence, these simulations did not capture the timing of the HTM and the gradient in the Nordic Seas as indicated by the diatom-based SST reconstructions. However, in the experiments of Renssen et al. (2009), the impact of the Greenland Ice Sheet (GIS) was not included, while potentially sea surface conditions in the western Nordic Seas were strongly influenced by GIS melt. Geological records (as reviewed in Funder et al., 2011) and modelling studies (Simpsonet al., 2009) agree that the GIS was bigger in the early Holocene compared to present day and may have reached its Holocene minimum at $6 \mathrm{ka} \mathrm{BP}$, followed by a regrowth. Estimates from Peltier's (2004) ICE5G model suggest a $25 \%$ larger GIS at $9 \mathrm{ka} \mathrm{BP}$ that loses mass until $7 \mathrm{kaBP}$ and expands again before returning to its present-day extension at $\sim 5 \mathrm{kaBP}$. Reconstructed GIS borehole site elevations from Vinther et al. (2009) indicate that these sites were $100-300 \mathrm{~m}$ higher for $9 \mathrm{ka}$ BP compared to today. Lower elevation sites such as Camp Century and Dye3 show a fast decrease in elevation in the early Holocene, whereas NGRIP and GRIP give a steady decrease from the early to the late Holocene. Consequently, both these estimates support the idea that in the early Holocene the GIS melt flux was larger than today. No quantified estimates of this early Holocene melt flux have yet been published, but based on Peltier (2004) we could infer a bestguess additional flux of $13 \mathrm{mSv}\left(1 \mathrm{~Sv}=1 \times 10^{6} \mathrm{~m}^{3} \mathrm{~s}^{-1}\right)$ for $9 \mathrm{kaBP}$.

How does this early Holocene GIS melt flux compare to projections of GIS melt for the present and the near future? Dickson et al. (2007) gave a modern-day estimate of GIS melt of $18 \mathrm{mSv}$ including melt and iceberg calving. For the past two decades Rignot et al. (2011) found an acceleration of Greenland mass loss of $21.9 \pm 1 \mathrm{Gtyr}^{-2}$, converting into $12.5 \mathrm{mSv}$ additional melt water during that period. Schrama and Wouters (2011) derived a similar estimate of mass loss 
acceleration ( $22 \pm 4 \mathrm{Gtyr}^{-2}$ ), which converts into $4.9 \mathrm{mSv}$ between 2003 and 2010. A simple extrapolation of these estimates yields $35 \pm 1.5 \mathrm{~cm}$ of sea level rise by 2100 , resulting from a steady increase of melt water flux of up to $80 \mathrm{mSv}$ by 2100 . Using a climate model coupled to a dynamical GIS model, Driesschaert et al. (2007) simulated a future retreat of the GIS within $3000 \mathrm{yr}$ under an extreme warming scenario, peaking with a relatively large melt rate of $0.1 \mathrm{~Sv}$ after $1000 \mathrm{yr}$, which has a noticeable weakening effect on the Atlantic Meridional Overturning Circulation (AMOC) in the model. However, when extrapolating the estimates from Rignot et al. (2011), such high melt rates would be reached soon after $2100 \mathrm{AD}$. Although these estimates assume a fixed acceleration rate, the impact on the AMOC highlights the importance of the GIS in future and in warmer past climates.

It is our objective in this paper to quantify the effect of GIS melt on the early Holocene climate in the Nordic Seas and to compare this impact with that of other important forcings by extending the modelling approach of Renssen et al. (2009). We present several transient simulations and force our model with a transient LIS deglaciation and a GIS melt water flux derived from Peltier (2004). We use an updated version of the model (ECBilt-CLIO-VECODE) previously employed by Renssen et al. (2009). This model has now been renamed to LOVECLIM (Goosse et al., 2010). We focus on the expression of the HTM in the Nordic Seas and aim to distinguish the impact of different forcings on SSTs. We will also evaluate which expression of SSTs in the Nordic Seas, as reconstructed using the different marine proxies, appears most consistent with our model results. In other words, does our model reproduce the clear east-west gradient and early timing of the HTM suggested by the diatom-based SST reconstructions, or rather a more uniform response across the Nordic Seas?

\section{Experimental design}

\subsection{The model}

We performed our experiments with the Earth system model of intermediate complexity (EMIC) LOVECLIM (version 1.2; Goosse et al., 2010), which includes a representation of the atmosphere, the ocean and sea ice, the land surface and its vegetation. We have not activated the components for dynamical ice sheets and the carbon cycle that are also included in LOVECLIM. We present here a brief summary of its key components, and more details can be found in Goosse et al. (2010). The sea-ice-ocean component is CLIO3 (Goosse and Fichefet, 1999), consisting of a free-surface ocean general circulation model with a horizontal resolution of $3^{\circ} \times 3^{\circ}$ latitude-longitude and 20 vertical levels, coupled to a sea ice component (Fichefet and Maqueda, 1997, 1999) employing a three-layer dynamic-thermodynamic model that simulates reasonably well the present-day Arctic sea ice distribution
(Goosse et al., 2007). The atmospheric component is ECBILT (Opsteegh et al., 1998), a spectral T21, three-level quasi-geostrophic model including a bucket-type hydrological model for soil moisture and runoff. Cloud cover is climatologically prescribed. The vegetation is handled by VECODE (Brovkin et al., 2002) a dynamical vegetation model simulating two plant types, trees and grasses and desert as a dummy type. We prescribed the ice sheets manually. The climate sensitivity of LOVECLIM (version 1.2) to a doubling of the atmospheric $\mathrm{CO}_{2}$ concentration is at the lower end of the range found in global climate models $(1.9 \mathrm{~K}$ after $1000 \mathrm{yr}$; Goosse et al., 2010). The simulated deep-ocean circulation in LOVECLIM1.2 compares reasonably well with other model results (Schmittner et al., 2005), with deep convection taking place in both the Nordic Seas and the Labrador Sea (Goosse et al., 2010). The model has been applied successfully in different palaeoclimatological modelling studies for settings like the $8.2 \mathrm{kaBP}$ event (Wiersma and Renssen, 2006) and the Holocene (Renssen et al., 2009).

\subsection{Experimental design}

In this study we discuss the results of four transient experiments that cover the last $9000 \mathrm{yr}$ and eight quasi-equilibrium snapshot experiments, seven with forcings fixed at $9 \mathrm{kaBP}$ and one with forcings for the pre-industrial era (summary in Table 1). Except for the experiment with pre-industrial forcings, the simulations were started at $9 \mathrm{ka}$ BP because before that time the influence of the Younger Dryas cold period may still have an important influence on the climate through the long-term memory of the deep ocean. We forced all simulations with orbital and greenhouse gas concentrations in line with the PMIP3 protocol (http://pmip3.lsce.ipsl.fr). An overview of the forcings is provided in Fig. 1.

\subsubsection{Snapshot experiments}

We performed one control snapshot experiment for background conditions at $9 \mathrm{kaBP}$ with orbital and greenhouse gas forcing $(9 \mathrm{kOG})$. This experiment was spun up for 1000 model years to ensure quasi-equilibrium conditions in all components of the model to the forcings (c.f. Renssen et al., 2006), implying that the mean global ocean temperature is stabilized. The final results of $9 \mathrm{kOG}$ have been used as initial conditions for all other $9 \mathrm{k}$ BP snapshot simulations which have a duration of 500 model years during which forcings were kept fixed. In PI and 9kOG, the land-sea mask, GIS topography, albedo, solar constant and aerosol content were fixed at PI configuration. The fixed land-sea mask will not likely impact the results as the difference in sea level between the two periods is only $19.71 \mathrm{~m}$ (9 ka BP; Siddall et al., 2003), implying that only a few grid cells are affected at the relatively low resolution of our model (i.e. T21 or about $560 \mathrm{~km} \times 560 \mathrm{~km}$ in the horizontal grid space for the atmosphere and $3^{\circ} \times 3^{\circ}$ latitude-longitude in the ocean). We 
Table 1. Summary of the experimental design. Transient forcings are shown in Fig. 1. Orbital parameters and greenhouse gases are in line with the PMIP3 protocol (http://pmip3.1sce.ipsl.fr/) for transient simulations. Laurentide Ice Sheet melt water fluxes are from Licciardi et al. (1999). Greenland Ice Sheet melt water fluxes are calculated from Peltier (2004) ice thickness changes.

\begin{tabular}{llll}
\hline $\begin{array}{l}\text { Experiment } \\
\text { name }\end{array}$ & Initial conditions & $\begin{array}{l}\text { GIS } \\
\text { Melt flux } \\
\text { (Sv) }\end{array}$ & $\begin{array}{l}\text { LIS } \\
\text { Melt flux } \\
\text { (Sv) }\end{array}$ \\
\hline 9kOG & & 0 & 0 \\
PI & Orbital (9000 BP), greenhouse gases (9000 BP) & 0 \\
9kOGx1 & Orbital (1950 AD), greenhouse gases (1750 AD) & 0 & 0 \\
9kOGx2 & 9kOG + Greenland Ice Sheet melt & 0.013 & 0 \\
9kOGx4 & 9kOG + Greenland Ice Sheet melt & 0.026 & 0 \\
9kOGMELT & 9kOG + Greenland Ice Sheet melt & 0.052 & 0.09 \\
9kOGMELTICE & 9kOGMELT + ice sheet (albedo + topography) & 0 & 0.09 \\
9kOGGIS & 9kOGMELTICE + GIS melt water & 0 & 0.09 \\
\hline OG & Transient orbital and greenhouse gases (9-0 ka BP) from PMIP3 3 & 0 & 0 \\
& transient simulation setup & 0.013 & $0.09-0$ \\
OGMELT & OG + Laurentide Ice Sheet melt water & 0 & $0.09-0$ \\
OGMELTICE & OGMELT + ice sheet (albedo + topography) & 0 & $0.09-0$ \\
OGGIS & OGMELTICE + GIS melt water & $0.026-0$ \\
\hline
\end{tabular}

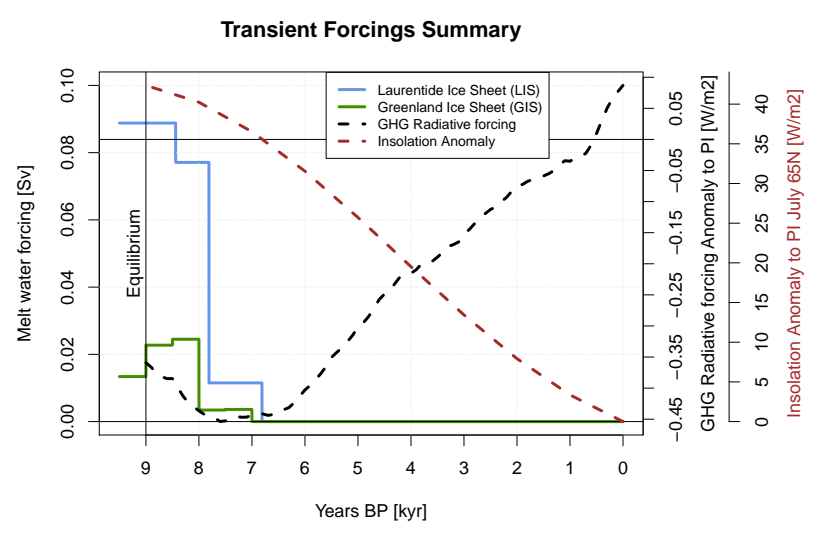

Fig. 1. Equilibrium and transient forcings applied in simulations. Shown are melt water forcings and orbital and greenhouse gas changes compared to the pre-industrial era. Topography changes of the LIS are not shown. Blue is the total LIS melt water flux applied in simulation OGMELT, OGMELTICE and OGGIS (left axis). The green curve denotes the calculated GIS melt water from Peltier (2004) prescribed in OGGIS (left axis). Black gives the radiative forcing due to greenhouse gas concentrations as anomaly to the pre-industrial era and the red curve gives the July $65^{\circ} \mathrm{N}$ insolation anomaly after Berger and Loutre (1991) (right axis). Greenhouse gas radiative forcing is calculated using IPCC (2001) formulation.

neglect changes to bathymetry in our simulations. Our analysis is based on averages that are calculated over the last $100 \mathrm{yr}$ of the simulations.

We performed three $9 \mathrm{kaBP}$ snapshot experiments to assess the sensitivity to the early Holocene GIS melt water flux
(Table 1: 9kOGx1, 9kOGx2, 9kOGx4). In these experiments, we prescribed multiples of a best-guess estimate of the early Holocene GIS melt flux of $13 \mathrm{mSv}$. This melt flux is derived from ice thickness changes provided at $500 \mathrm{yr}$ time steps by the Peltier (2004) ICE-5G model. We add the additional melt water to the normally calculated surface runoff (i.e. sum of excess precipitation and snow melt), which is then evenly distributed over 10 major runoff points (c.f. Bakker et al., 2012) for locations of river outflow points.

In two additional snapshot experiments (9kOGMELT, 9kOGMELTICE) we added the LIS forcing to the impact of $9 \mathrm{ka}$ BP orbital and greenhouse forcing, identical to Renssen et al. (2009). In these experiments, we separately investigate the effect of an additional freshwater flux $(0.09 \mathrm{~Sv}$, denoted by MELT), representing the background melting of the LIS introduced at the St. Lawrence River outlet and Hudson Bay outlet, and the total effect of the remnant LIS (i.e. additional freshwater, albedo and topography changes) indicated by the name MELTICE. In agreement with palaeoceanographic evidence (Hillaire-Marcel et al., 2001, 2007), Labrador Sea convection was suppressed by the LIS background melt flux.

Finally, we performed an equilibrium experiment (9kOGGIS) in which we combined all forcings of the previous one (9kOGMELTICE), and in addition included the best-guess GIS melt flux of $13 \mathrm{mSv}$.

\subsubsection{Transient experiments}

We performed one transient control simulation (OG) including only transient orbital and greenhouse gases and two transient simulations including additionally either LIS melt water (OGMELT) or the full LIS forcing (OGMELTICE). Following the setup of Renssen et al. (2009), the additional 
freshwater flux was set to $0.09 \mathrm{~Sv}$ between 9 and $8.4 \mathrm{kaBP}$, decreasing slightly to $0.08 \mathrm{~Sv}$ between 8.4 and $7.8 \mathrm{kaBP}$, and dropping to $0.01 \mathrm{~Sv}$ between 7.8 and $6.8 \mathrm{ka} \mathrm{BP}$ (Fig. 1). These freshwater rates are based on adapted estimates of Licciardi et al. (1999) and do not include short-term freshwater drainage events such as the $8.2 \mathrm{ka} \mathrm{BP}$ event because the focus of our study is on multi-centennial to millennial timescales. In OGMELTICE the effect of the disintegrating LIS was accounted for by changing the surface albedo and topography at $50 \mathrm{yr}$ time steps, interpolated from reconstructions provided by Peltier (2004), during the period 9 to $7 \mathrm{kaBP}$.

Finally, we performed a transient experiment (OGGIS) that included the GIS melt water flux, in addition to all forcings prescribed in OGMELTICE. As shown in Fig. 1, the additional melt water was set to $13 \mathrm{mSv}$ for $9 \mathrm{ka} \mathrm{BP}$ and increases to $23 \mathrm{mSv}$ from 9 to $8 \mathrm{kaBP}$ and then rapidly decreases to $3 \mathrm{mSv}$ before vanishing completely at $7 \mathrm{ka} \mathrm{BP}$ (estimates derived from Peltier (2004)). Considering the coarse model grid resolution (T21), early Holocene GIS topography changes in the model are relatively small and are therefore neglected in this study.

\section{Results and discussion}

We separate our results into two sections. Section 3.1 presents the results of the equilibrium experiments on the early Holocene and discusses the impact of different forcings, and Sect. 3.2 presents the results for the transient simulations and the timing of the HTM together with some proxy estimates of the timing.

\subsection{Early Holocene response}

Simulations including GIS melt $(9 \mathrm{kOGx} 1,2,4)$ show a clear August SST response near the southern part of Greenland although the GIS melt is evenly distributed around Greenland. Compared to experiment 9kOG, in 9kOGx1 (Figs. 2a, 3a) $13 \mathrm{mSv}$ of melt water reduces SSTs and SSSs around the southern tip of Greenland, and especially the region near Denmark Strait is affected, with lowest values at about $-3 \mathrm{~K}$ and $-2 \mathrm{psu}$, respectively. For a doubling of GIS melt $(26 \mathrm{mSv}$ ) in experiment 9kOGx2 (Figs. 2b, 3b) the geographical pattern is quite similar to $9 \mathrm{kOGx} 1$, but with a more pronounced cooling of up to $3 \mathrm{~K}$ near Denmark Strait and a SSS reduction of up to -3 psu. Noticeable is also the development of a cold tongue across the Nordic Seas to the eastern side accompanied by a decrease in salinity as well. Changes in 9kOGx4 (52 mSv, Figs. 2c, 3c) are hugely different from previous experiments. The core area of cooling is now in the Labrador Sea with more than $5 \mathrm{~K}$ cooling as the deep convection is locally shut down here. The reduction of SSSs is strongest inside Hudson Bay and to the southeast of
Greenland. This affects most of the North Atlantic as well as the northern Nordic Seas.

In the early Holocene the Laurentide Ice Sheet puts great amounts $(50 \mathrm{mSv}$ in Hudson Strait and $40 \mathrm{mSv}$ in the St. Laurence outlet) of freshwater into the adjacent ocean. In experiment 9kOGMELT (Figs. 2d, 3d), cooling due to this LIS melt water is affecting primarily the Labrador Sea, with a cooling of up to $5 \mathrm{~K}$ and a freshening of more than 3 psu. This cooling is due to the local shutdown of deep convection in the Labrador Sea (as expressed by mixed layer depth (MLD) changes in Fig. 5c in the Labrador Sea), similar to what is seen here in $9 \mathrm{kOGx} 4$. However, compared to the latter experiment, there is less cooling impact on the rest of the North Atlantic and the Nordic Seas in 9kOGMELT. Including the remnant LIS into experiment 9kOGMELTICE (Fig. 2e) further reduces SSTs (by more than $6 \mathrm{~K}$ ) in the Labrador Sea and enhances cooling downwind of the ice sheet. Additional cooling affects the northern Nordic Seas, whereas a more than $2 \mathrm{~K}$ warming appears in a small area in the western Nordic Seas, near Denmark Strait. The comparison with Fig. 3e shows that SSSs are increased near Denmark Strait, resulting from an increase of convective activity there as previously discussed in Renssen et al. (2010). This can be seen as well in Fig. 5c by an increase in MLD compared to Fig. 5a. Ultimately combining the LIS forcing with one-time GIS melt $(13 \mathrm{mSv})$ in experiment 9kOGGIS (Figs. 2f, 3f) further reduces western Nordic Seas SSTs. Compared to 9kOGMELTICE, the warming near Denmark Strait is reversed into a cooling that now expands across the Nordic Seas. SSS values near Denmark Strait are very similar in 9kOGGIS and 9kOG.

\subsubsection{Comparison with proxy-based SSTs}

Based on diatoms, Andersen et al. (2004) find a positive east-west August SST difference of 6 to $7 \mathrm{~K}$ for the early Holocene, whereas using alkenone-based summer SSTs (Calvo et al., 2002) for the eastern side yields a difference of 3 to $4 \mathrm{~K}$. We find in our experiment $9 \mathrm{kOG}$ an annual difference of $\sim 6$ and $\sim 4 \mathrm{~K}$ for August SSTs (Fig. 4). Modelling suggests zonal differences are greatest in winter when the contrast between eastern and western water masses is greatest, as can be seen in Fig. 4 by February east-west differences of 7 to $8 \mathrm{~K}$. Including GIS melt in 9kOGx1 increases August and annual SST differences by $0.5 \mathrm{~K}$ as compared to $9 \mathrm{kOG}$. Experiment 9kOGx2 and 9kOGx4 reveal that a larger GIS melt leads to a slightly smaller east-west difference, caused by an eastward spreading of the cold anomaly (compare with Fig. 4). In experiment 9kOGMELT the difference is almost not affected as compared to 9kOG, but in 9kOGMELTICE a clear reduction of the difference is evident, with annual mean values around $\sim 4 \mathrm{~K}$ compared to $6 \mathrm{~K}$ in $9 \mathrm{kOG}$. Along with this smaller difference, a decrease in variability can be noted by smaller standard deviations. Finally, in 9kOGGIS the east-west SST difference increases again to similar values as in $9 \mathrm{kOGx} 1$. However, note that all simulations are 


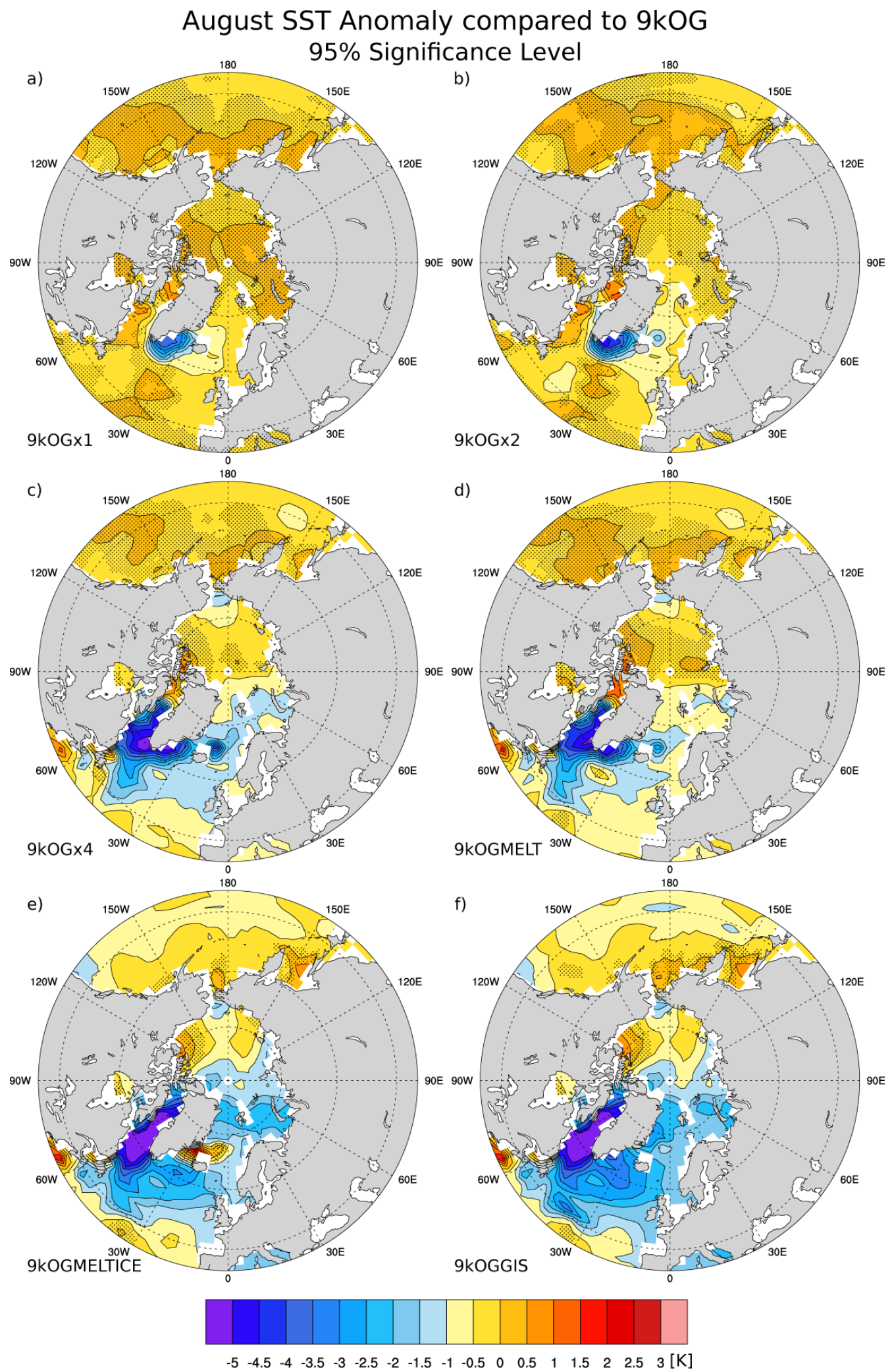

Fig. 2. Sea surface temperature (SST, scale in K) anomaly compared to $9 \mathrm{kOG}$ for $9 \mathrm{ka} \mathrm{BP}$ snapshot simulations. Values are calculated from the last $100 \mathrm{yr}$ of each experiment. Shaded area denotes insignificant changes compared to 9kOG according to a Student's $t$ test. (a) $9 \mathrm{kOGx} 1$ SST anomaly for GIS melt ( $13 \mathrm{mSv})$. (b) $9 \mathrm{kOGx} 2 \mathrm{SST}$ anomaly for GIS melt $(26 \mathrm{mSv})$. (c) 9kOGx4 SST anomaly for GIS melt (52 mSv). (d) $9 \mathrm{kOGMELT} \mathrm{SST}$ anomaly for LIS melt $(0.09 \mathrm{~Sv})$. (e) 9kOGMELTICE SST anomaly for LIS melt $(0.09 \mathrm{~Sv})+$ remnant ice sheet (albedo + topography). (f) 9kOGGIS SST anomaly for LIS melt + remnant ice sheet + additional GIS melt (13 mSv). 

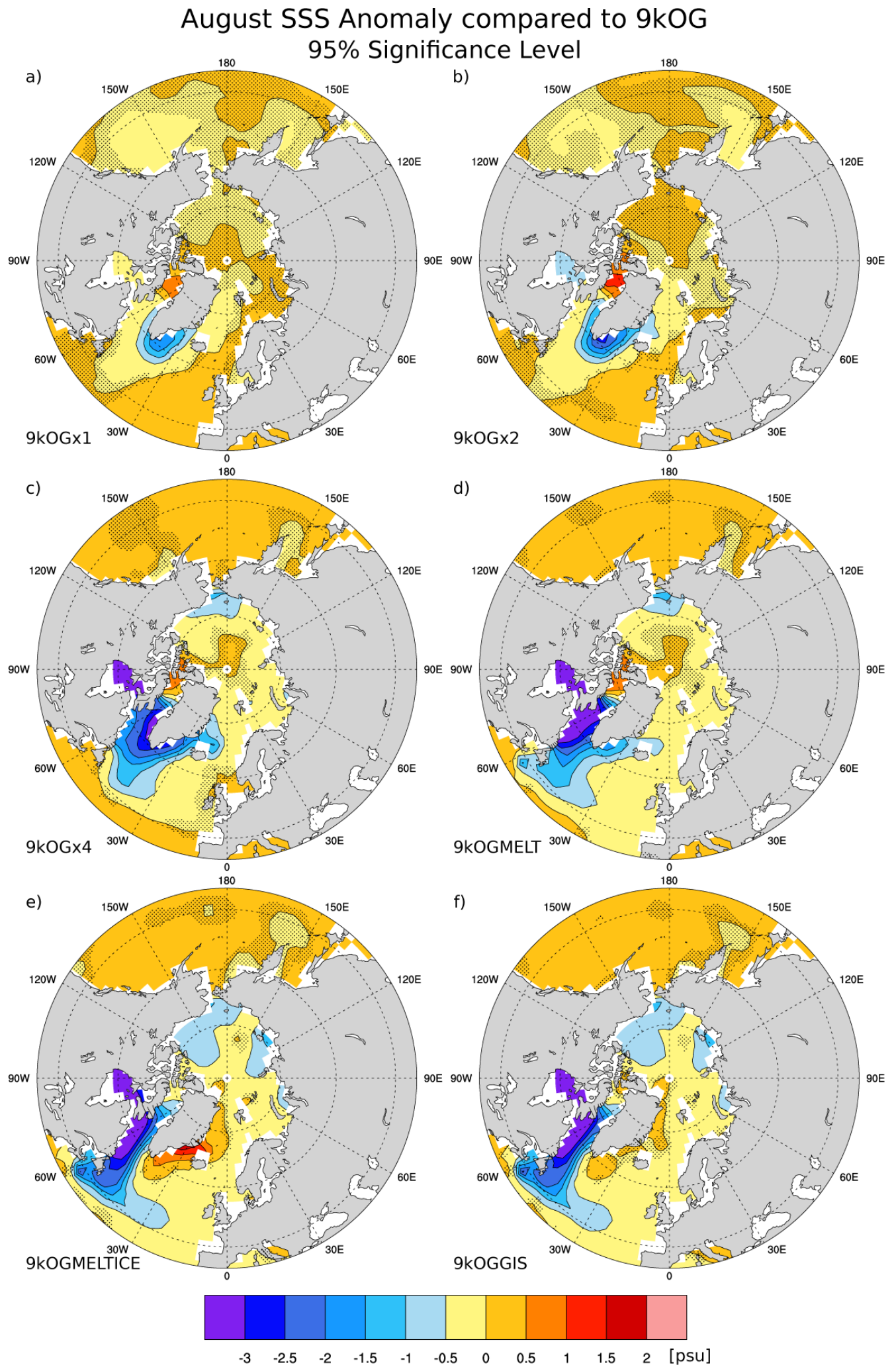

Fig. 3. Sea surface salinity (SSS, scale in psu.) anomaly compared to OG for $9 \mathrm{ka} \mathrm{BP}$ snapshot simulations. Values are calculated from the last $100 \mathrm{yr}$ of each experiment. Shaded area denotes insignificant changes compared to 9kOG according to a Student's $t$ test. (a) $9 \mathrm{kOGx} 1$ SSS anomaly for GIS melt (13 mSv). (b) 9kOGx2 SSS anomaly for GIS melt (26 mSv). (c) 9kOGx4 SSS anomaly for GIS melt (52 mSv). (d) 9kOGMELT SSS anomaly for LIS melt $(0.09 \mathrm{~Sv})$. (e) $9 \mathrm{kOGMELTICE} \mathrm{SSS} \mathrm{anomaly} \mathrm{for} \mathrm{LIS} \mathrm{melt}(0.09 \mathrm{~Sv})+$ remnant ice sheet (albedo + topography). (f) 9kOGGIS SSS anomaly for LIS melt + remnant ice sheet + additional GIS melt (13 mSv). 


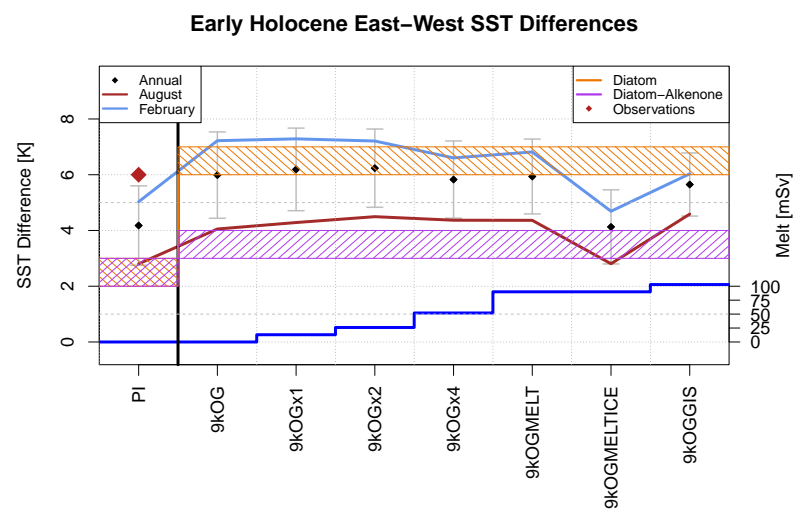

Fig. 4. Simulated east-west SST differences across the Nordic Seas for $9 \mathrm{ka} \mathrm{BP}$ snapshot simulations and an additional present-day (PI) simulation for comparison. Corresponding eastern model area 47.5$10^{\circ} \mathrm{W}, 68.75-81.25^{\circ} \mathrm{N}$ and western $2.5-20^{\circ} \mathrm{E}, 66.25-78.75^{\circ} \mathrm{N}$. Points mark the annual mean difference, grey bars give associated standard deviation, red line gives August value and light-blue line gives February value. Values are calculated from the last $100 \mathrm{yr}$ of each experiment. Dark-blue line at the bottom gives the total amount of freshwater added to the simulations in $\mathrm{mSv}$. Orange bar indicates diatom-based SST differences. The value shown in purple is constructed from Andersen et al. (2004) by combining the diatombased SST estimate in the western Nordic Seas and the alkenonebased value (Calvo et al., 2002) in the eastern Nordic Seas. Red square indicates modern day value from Smith et al. (2008) in the period of 1854 to $1950 \mathrm{AD}$.

significantly different from 9kOG according to a Student's $t$ test (c.f. Table 2) and that the mentioned reduced variability is insignificant.

We find that GIS melt increases the east-west difference and generates a model climate closer to the proxy-based reconstructions. Our simulations have not been able to fully reproduce the diatom-based east-west difference, because in our model it was not possible to increase summer SSTs to values as high as reconstructed based on diatoms in the eastern Nordic Seas. However, if we take the alkenone-based SSTs in the east and combine this with diatom-based SSTs in the west, there is good agreement with the simulated August SST differences. One could argue that it is preferable to compare model results to reconstructions based on a single proxy, but on the other hand a particular proxy could also be more suited for SST reconstructions at one location than another proxy. MARGO Project Members (2009) have shown for the Last Glacial Maximum that in the Nordic Seas, large discrepancies exist in palaeotemperature reconstructions based on microfossil proxies, and that it is unclear how to reconcile. We thus propose that this may also be true for the early Holocene. In any case, a lower eastwest difference compares better to our model results. The difference is strongest in winter. In conclusion, the better
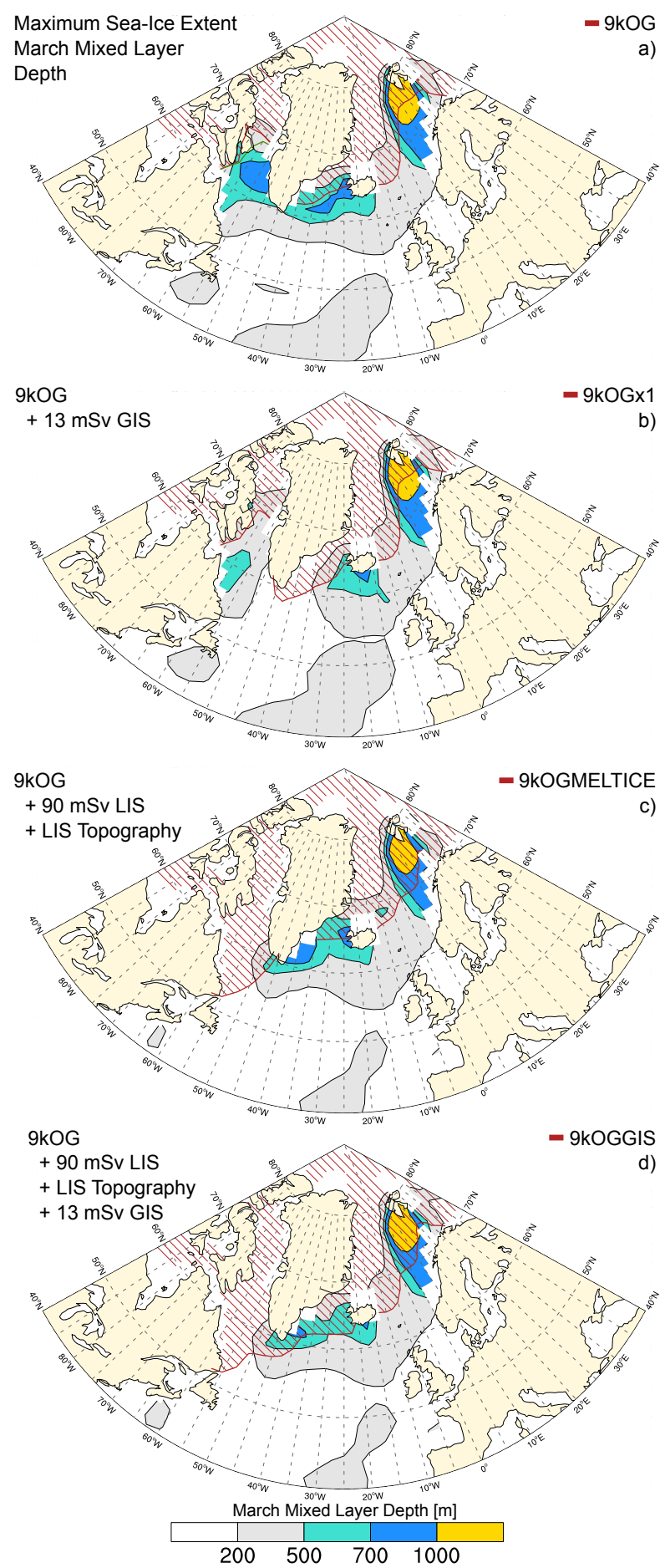

Fig. 5. March mixed layer depth (MMLD, in metres) and winter maximum sea ice concentration (SIC) over $15 \%$, denoting sea ice extent. Values are calculated from the last $100 \mathrm{yr}$ of each experiment. (a) shows MMLDs for simulation 9kOG and SIC for simulation 9kOG. (b) shows MMLDs for simulation 9kOGx1 and SIC. (c) shows MMLDs for simulation 9kOGMELTICE and SIC. (d) shows MMLDs for simulation 9kOGGIS and SIC. 
Table 2. Summary of key variables from all snapshot simulations. Mean and standard deviation of the (1) maximum meridional overturning stream function in the Nordic Seas and the North Atlantic at $27^{\circ} \mathrm{N}$, (2) sea ice area and volume in the Northern Hemisphere, (3) North Atlantic Deep Water exported south at $20^{\circ} \mathrm{S}$, (4) meridional heat flux in the Atlantic ocean at the equator and (5) Nordic Seas east-west August SST difference. Values are calculated from the last $100 \mathrm{yr}$ of each experiment.

\begin{tabular}{|c|c|c|c|c|c|c|c|c|}
\hline \multirow[b]{3}{*}{ 9kOG } & \multicolumn{4}{|c|}{ Maximum Overturning Stream Function in } & \multicolumn{4}{|c|}{ Sea Ice } \\
\hline & \multicolumn{2}{|c|}{ Nordic Seas [Sv] } & \multicolumn{2}{|c|}{ North Atlantic [Sv] } & \multicolumn{2}{|c|}{ Area $\left[10^{6} \mathrm{~km}^{2}\right]$} & \multicolumn{2}{|c|}{ Volume $\left[10^{3} \mathrm{~km}^{3}\right]$} \\
\hline & 2.78 & \pm 0.15 & 13.93 & \pm 2.31 & 8.80 & \pm 0.24 & 8.86 & \pm 0.62 \\
\hline 9kOGx1 & 2.80 & \pm 0.15 & 12.83 & \pm 2.35 & 8.94 & \pm 0.22 & 9.00 & \pm 0.52 \\
\hline $9 \mathrm{kOGx} 2$ & 2.88 & \pm 0.16 & 12.47 & \pm 2.33 & 9.00 & \pm 0.26 & 9.16 & \pm 0.60 \\
\hline $9 \mathrm{kOGx} 4$ & 2.72 & \pm 0.28 & 9.78 & \pm 2.45 & 9.72 & \pm 0.41 & 10.06 & \pm 0.88 \\
\hline 9kOGMELT & 2.75 & \pm 0.17 & 9.27 & \pm 2.40 & 9.58 & \pm 0.30 & 9.87 & \pm 0.79 \\
\hline 9kOGMELTICE & 2.53 & \pm 0.21 & 10.10 & \pm 2.50 & 10.26 & \pm 0.29 & 11.29 & \pm 0.80 \\
\hline 9kOGGIS & 2.65 & \pm 0.19 & 9.47 & \pm 2.50 & 10.37 & \pm 0.26 & 11.36 & \pm 0.71 \\
\hline
\end{tabular}

\begin{tabular}{llcllll}
\hline & \multicolumn{2}{l}{ NADW Export [Sv] } & \multicolumn{2}{l}{$\begin{array}{l}\text { Oceanic } \\
\text { Heat Flux }\end{array}$} & $\begin{array}{c}\text { Meridional } \\
\text { N [PW] }\end{array}$ & \multicolumn{2}{l}{$\begin{array}{l}\text { East-West August SST } \\
\text { Difference [K] }\end{array}$} \\
\hline 9kOG & 9.78 & \pm 0.50 & 0.447 & \pm 1.001 & 3.82 & \pm 0.60 \\
9kOGx1 & 9.81 & \pm 0.47 & 0.423 & \pm 0.994 & 4.39 & \pm 0.57 \\
9kOGx2 & 9.55 & \pm 0.42 & 0.414 & \pm 1.018 & 4.25 & \pm 0.53 \\
9kOGx4 & 9.66 & \pm 0.63 & 0.338 & \pm 1.041 & 4.08 & \pm 0.87 \\
9kOGMELT & 9.41 & \pm 0.67 & 0.331 & \pm 1.037 & 4.07 & \pm 0.81 \\
9kOGMELTICE & 9.60 & \pm 0.74 & 0.347 & \pm 1.059 & 2.80 & \pm 0.88 \\
9kOGGIS & 9.52 & \pm 0.56 & 0.334 & \pm 1.052 & 4.51 & \pm 1.05 \\
\hline
\end{tabular}

Italic numbers are significant changes as compared to 9kOG according to a Student's $t$ test.

model-data fit in the experiments with the GIS melt indicates that it is important to include the GIS melt in simulations of Holocene climate in the Nordic Seas. In other words, we propose that the impact of GIS melt has been registered in the proxies, producing the observed SST difference across the Nordic Seas in the early Holocene. Simulation 9kOGGIS includes all presented forcings and still agrees to some extent to the proxy reconstructions, meaning that the results are more complete as compared to the other simulations. Regarding the foraminifera-based SSTs, our model shows that seasonal summer warming in the early Holocene is mainly active in the upper $\sim 100 \mathrm{~m}$ (not shown), in line with findings of Andersson et al. (2010) for the mid-Holocene. Our model further shows that GIS melt affects only the uppermost $50 \mathrm{~m}$ of the water column (not shown). Therefore, it is likely that deeper dwelling foraminifera species were less affected by orbitally forced summer warming and GIS melt as compared to surface dwellers.

According to Risebrobakken et al. (2011), this was likely the case, implying that these deeper species record an early Holocene increase of horizontal heat advection that weakens towards the present. However, in our experiments an increase of horizontal heat advection cannot be found.

\subsubsection{Mechanisms behind SST patterns}

As discussed in Sect. 3.1.1, we have simulated clear cooling patterns in the Labrador Sea, the Irminger Sea and the Nordic Seas. But, what has caused these cooling patterns? In our simulations we find the impacts of the following forcings on August SSTs: $F 1$, GIS melt near Greenland; F2, LIS melt water in the Labrador Sea; $F 3$, the topography and surface albedo of the remnant LIS; and $F 4$, the combination of all forcings.

We would like to give a brief summary of the mechanisms connected to these forcings.

We find that forcings $F 1$ and $F 2$ freshen the upper ocean and reduce oceanic vertical heat transfer by limiting downward summer heat transfer. Connected to this freshening of the ocean surface we find increased sea ice growth accompanied by stratification of the upper water column and inhibiting convection in winter. This is clearly related to forcing $F 2$ and on a smaller scale also to $F 1$, near Denmark Strait. We find an amplification of the sea ice expansion and associated stratification by the downwind atmospheric cooling from a large ice sheet, which is mainly related to forcing $F 3$. These three effects (i.e. (1) upper-ocean freshening, (2) sea ice expansion and (3) downwind cooling from the LIS) will be discussed in more detail in the following paragraphs and are mostly active in combination with each other. 
The pattern found in SSTs from Greenland melt water (Fig. 2a, b, 9kOGx1, 2) is a result of freshening and stratifying the upper-ocean column.

Surface waters become more buoyant, and the density difference with the subsurface increases (up to $0.18 \mathrm{~kg} \mathrm{~m}^{-3}$ from 5 to $100 \mathrm{~m}$ depth for $9 \mathrm{kOGx} 1$ ), thus reducing vertical heat transfer and causing surface cooling (note that we do not show this directly, but it can be inferred from Fig. 5a and $b$ as changes in MLD near the southern tip of Greenland). In general, the southern tip of Greenland is where the freshwater (runoff, sea ice) from the Arctic and Greenland results in the largest cooling in 9kOGx1 and 9kOGx2. In the Arctic Ocean, however, surface waters are already quite fresh (c.f. 3a, b) and stratified, minimizing the effect of additional melt water. As a consequence of cooler and fresher surface waters, sea ice growth is facilitated at the southern tip of Greenland and local convection in winter is reduced (9kOGx1) by up to $-200 \mathrm{~m}$ of maximum convection depth relative to $9 \mathrm{kOG}$ (not shown, but note the reduction in MLD Fig. 5b), assisting in an overall cooling effect.

Considering the combined effect of all mentioned forcings (by comparing 9kOGGIS to 9kOG), the Northern Hemisphere sea ice area and volume increase by up to $18 \%$ and $28 \%$ (Table 2), respectively, with the biggest changes in the Labrador Sea area (c.f. Fig. 5a, d sea ice extent), while the increases are minor in the Nordic Seas. The strong cooling in the Labrador Sea is linked to a local collapse of deep convection and expansion of sea ice cover as a result of strong surface freshening here. In 9kOGGIS this freshening is primarily resulting from LIS melt (c.f. Renssen et al., 2005, 2009), but the same effect is seen when GIS melt is increased, as in $9 \mathrm{kOGx} 4$ (Fig. 3c). The absence of deep convection in the Labrador Sea results in a reduction of meridional overturning strength in the North Atlantic (Fig. 5c, d).

The simulated deep-ocean circulation for $9 \mathrm{kOG}$ has a maximum overturning stream function at $27^{\circ} \mathrm{N}$ of $13.9 \pm 2.3 \mathrm{~Sv}$ (AMOC, Table 2) and an export of North Atlantic Deep Water (NADW) towards the Southern Ocean of $9.8 \pm 0.5 \mathrm{~Sv}$. Observed values for the AMOC strength at $26.5^{\circ} \mathrm{N}$ for $2004-2008$ by Kanzow et al. (2010) are somewhat higher $(18.7 \mathrm{~Sv})$ but variable alike $( \pm 2.1 \mathrm{~Sv})$.

In LOVECLIM, deep convection takes place in both the Nordic Seas and the Labrador Sea, similar to the conditions in a simulation with pre-industrial forcings (Goosse et al., 2010). In our experiments the GIS melt has a discernible impact on convection depth near Denmark Strait which is contributing to the North Atlantic overturning. In $9 \mathrm{kOGx} 1$ a reduction of $\sim 8 \%(12.8 \mathrm{~Sv}$ vs. $13.9 \mathrm{~Sv}$, Table 2$)$ of the maximum meridional overturning strength is simulated as compared to $9 \mathrm{kOG}$. As expected, the AMOC weakens further when also LIS melt is included, resulting in similarly reduced values of the maximum meridional overturning strength in 9kOGMELTICE (10.1 Sv) and in 9kOGGIS $(9.5 \mathrm{~Sv})$. This weakening corresponds to a reduced annual northward heat transport in the ocean at the equator in the
Atlantic Basin of $25 \%$ for 9kOGGIS (0.334 PW) as compared to $9 \mathrm{kOG}(0.447 \mathrm{PW})$, contributing to the cooling of the Northern Hemisphere. This is best expressed in 9kOGx4 ( $\sim 24 \%$ reduction) and 9kOGMELT ( $\sim 26 \%$ reduction) as in these experiments the impact on meridional overturning strength is the largest.

Another superimposed effect contributes to cooler North Atlantic SSTs in 9kOGMELTICE and 9kOGGIS, which is the enhanced cooling (by $2 \mathrm{~K}$ in $9 \mathrm{kOGMELTICE}$ vs. $0.5 \mathrm{~K}$ in 9kOGMELT: Figs 2e, f) downwind of the remnant LIS as discussed in detail in Renssen et al. (2009). Meridional overturning in the Nordic Seas and therefore NwAC (Norwegian Atlantic Current) strength are weakly affected (c.f. Table 2) by overall cooling and freshening $(2.65 \mathrm{~Sv}$ in $9 \mathrm{kOGGIS}$ vs. $2.78 \mathrm{~Sv}$ in $9 \mathrm{kOG}$ ) because of their competing effects on surface density and therefore convective activity. In the Nordic Seas at the main deep convection site southwest of Svalbard, the freshening is relatively modest (as compared to the Labrador Sea, Fig. 3). The reduction in surface density resulting from this freshening is almost compensated by the increase in density caused by the surface cooling (not shown, c.f. Figs. 2, 3). As a consequence, maximum winter convection depth is reduced by $200 \mathrm{~m}$ in 9kOGGIS as compared to $9 \mathrm{kOG}$ at the convection site (not shown). These findings are accompanied by a slight (5\%) reduction of the northward heat flux into the Nordic Seas $\left(\right.$ at $\left.60^{\circ} \mathrm{N}\right)$ in simulation 9kOGGIS as compared to 9kOG. Therefore, our model experiments do not support the idea that higher summer SSTs were caused by increased inflow of warm Atlantic waters as proposed by Risebrobakken et al. (2011). However, in other modelling studies - for instance Swingedouw et al. (2012), Kleinen et al. (2009) and Stouffer et al. (2006) - such increase in warm inflow is simulated in response to surface ocean freshening.

\subsection{Transient Holocene response}

From our snapshot simulations we could derive a discernible response to GIS melt that seems to be visible also in the proxy-based reconstructions and is denoted by an increased August SST gradient across the Nordic Seas in the early Holocene. Therefore we want to investigate the temporal evolution of this impact on the HTM.

\subsubsection{Simulated SST trends}

The modelled Nordic Seas' SST difference responds more strongly to GIS melt water than to effects inflicted by the remnant Laurentide Ice Sheet. The eastern Nordic Seas SSTs in OG show a clear early HTM (before $8 \mathrm{ka} \mathrm{BP}$ ) and a subsequent decline towards pre-industrial temperatures. LIS melt water in OGMELT has a minor effect on the Nordic Seas (less than $0.5 \mathrm{~K}$ difference). In contrast, in OGMELTICE the additional remnant ice sheet reduces SSTs by $1.5 \mathrm{~K}$ in the early Holocene (Fig. 6a) relative to OG. With the ice 


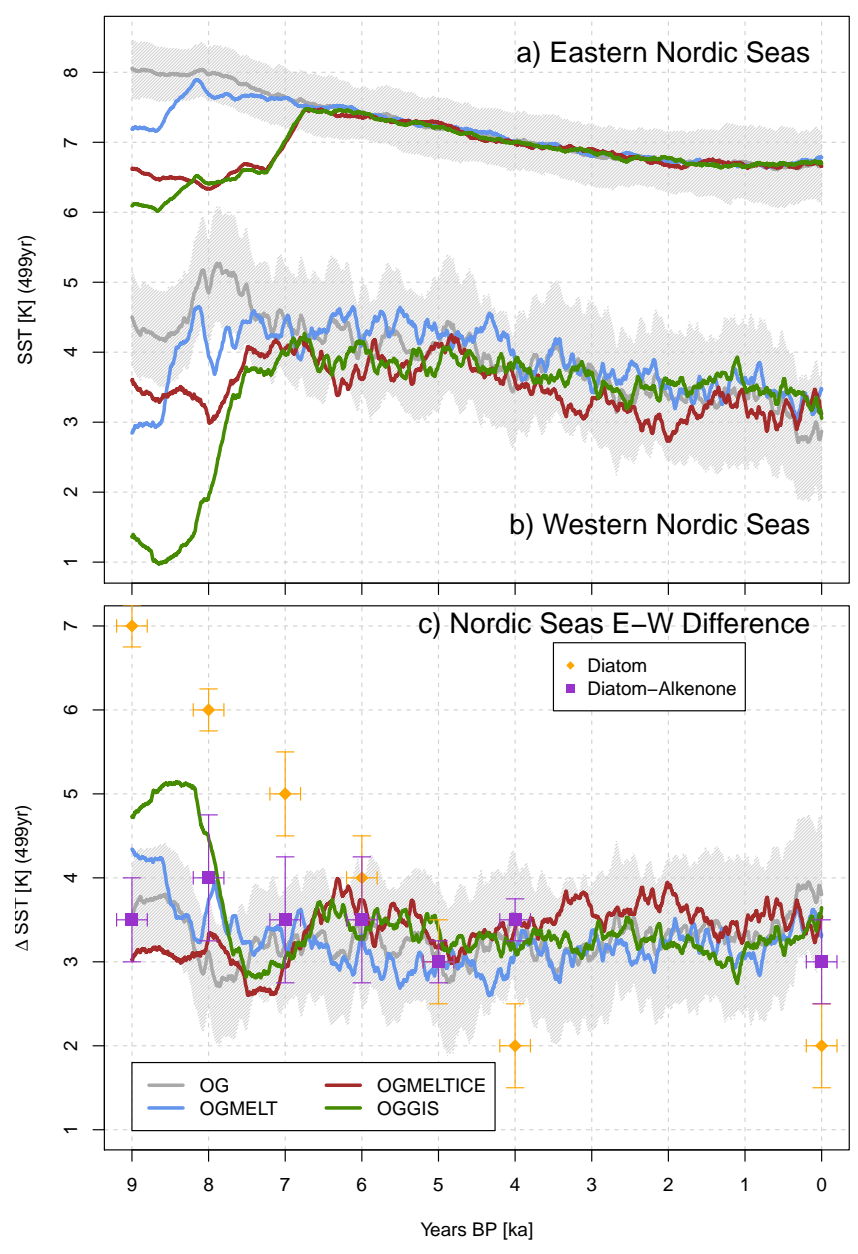

Fig. 6. Transient area weighted August SSTs for eastern and western Nordic Seas and the difference from four transient simulations. (a) August SST in the eastern Nordic Seas $\left(2.5-20^{\circ}\right.$ E, 66.25$78.75^{\circ} \mathrm{N}$ ) from 9 to $0 \mathrm{ka} \mathrm{BP}$. (b) August SST in the western Nordic Seas $\left(47.5-10^{\circ} \mathrm{W}, 68.75-81.25^{\circ} \mathrm{N}\right)$ from 9 to $0 \mathrm{kaBP}$. (c) August east-west SST difference across the Nordic Seas from 9 to 0 ka BP. Grey represents OG; blue, OGMELT; red, OGMELTICE; and green, OGGIS. The grey area denotes the standard deviation of simulation OG. Orange dots represent approximate values from Andersen et al. (2004) for diatom-based SST gradient. The values shown in purple are constructed from Andersen et al. (2004) by combining the diatom-based SST estimate in the western Nordic Seas and the alkenone-based values (Calvo et al., 2002) in the eastern Nordic Seas. Error bars denote approximate errors of mean values in time (default 200 yrs) and magnitude.

sheet vanishing at around $7 \mathrm{ka} \mathrm{BP}$, temperatures return to the general orbitally forced trend during the remainder of the Holocene, depicted by simulation OG. The GIS melt affects previously mentioned results only in the first $500 \mathrm{yr}$, when GIS melt is at its peak, causing warmer conditions by $0.5 \mathrm{~K}$. In contrast, SSTs in the western Nordic Seas (Fig. 6b) are more strongly reduced by GIS melt (by $\sim 3 \mathrm{~K}$ ) in OGGIS than by the influence of the LIS in OGMELTICE $(\sim 2 \mathrm{~K})$.
This impact wears off at $7.5 \mathrm{ka} \mathrm{BP}$, when temperatures return to the general cooling trend displayed by OG. The noted different effects in the western and eastern Nordic Seas clearly indicate that the difference across the Nordic Seas is more influenced by GIS melt and less by the remnant LIS. Simulated SSTs for the east (Fig. 6a) and west (Fig. 6b) decrease over time, whereas in Fig. 6c the difference is mostly constant over the Holocene, except for the early and late Holocene. The east-west difference is clearly stronger in OGGIS than in OGMELTICE because of the strong impact of GIS melt water. As soon as GIS melt vanishes, the difference in OGGIS returns to the same level as the other experiments. A more gradual decrease, as seen in proxy reconstructions (Andersen et al., 2004), would only have been simulated with continued additional GIS melt water fluxes after $7 \mathrm{ka} \mathrm{BP}$. We could thus speculate that we underestimated GIS melt and/or the increase of sea ice cover over the western side in our experiments.

\subsubsection{Impact on the HTM}

The spatial pattern of the HTM timing is mainly influenced by the remnant LIS, and secondly but fundamentally in the Nordic Seas, by GIS melt (Fig. 7). Our main interest here is in the millennial-scale trend. To filter out decadal to centennial variability, we used a $1000 \mathrm{yr}$ running mean and calculated the timing (in yr BP) of the maximum for August SSTs. Relative to OG, peak warmth is delayed by up to $3500 \mathrm{yr}$ in the Nordic Seas, and is highly variable between the four transient simulations. In OGMELT, the LIS delays the timing of the HTM over the whole North Atlantic by $\sim 1000 \mathrm{yr}$ (Fig. 7a, b). Denmark Strait and the region south of it show HTM timings $\sim 2000 \mathrm{yr}$ later than in OG. A major step happens by including the remnant ice sheet in OGMELTICE, which further increases the timing delay to $2000-2500 \mathrm{yr}$ for large parts of the North Atlantic. The eastern Nordic Seas are delayed by $2000 \mathrm{yr}$, whereas the delay on the western side ranges between 500 and $2500 \mathrm{yrs}$, suggesting a westeast spatial timing difference, rather than an east-west difference. Including the GIS melt in OGGIS uniformly delays the HTM on the western side, resulting in a spatial timing difference of $2000 \mathrm{yr}$ across the Nordic Seas. It should be noted that the HTM timing in our transient experiment depends strongly on the timescale of the applied forcings. Therefore, it is preferable to consider the relative timings (i.e. timing delays compared to orbital and freshwater forcing) when comparing with proxy data, as explained in Sect. 3.2.3.

\subsubsection{Proxy trends and timings}

Despite uncertainties in model and proxy results, the combination of LIS and GIS forcings link reconstructed and modelled estimates of SST trends and the timing of the HTM. The zonal Nordic Seas SST difference in Andersen et al. (2004) decreases less abruptly than our associated modelled SST 


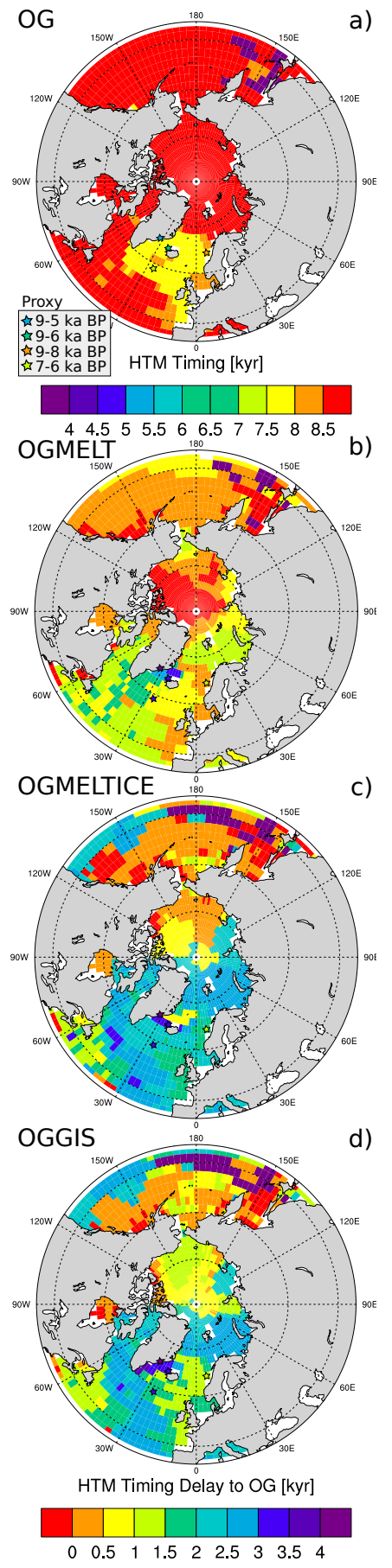

Fig. 7. Timing of the Holocene thermal maximum (in yr BP) based on simulated August SSTs in the Northern Hemisphere. The timing is taken to be the maximum of a $1000 \mathrm{yr}$ running-meanfiltered August SST time series. Proxy core locations are indicated by stars: BS-88-06-5A (near Greenland); MD99-2269 (North Iceland); MD95-2011 (near Norway); MD95-2015 (Gardar Drift). The colours of the stars represent the minimum of the HTM timing (a) and the maximum of the HTM delay (b, c, d). Estimates of HTM timing are shown in the top figure. (a) shows simulation OG in absolute timing, (b) shows simulation OGMELT as delays compared to OG, (c) shows simulation OGMELTICE as delays compared to OG and (d) shows simulation OGGIS as delays compared to OG. difference. However, given the step-like nature of our prescribed melt fluxes an abrupt termination is inevitable. We calculate SST trends from the early Holocene maximum to the pre-industrial minimum for both proxy and model results. Therefore the time interval of the trends vary. Reconstructed proxy SST trends from Andersen et al. (2004) are $5 \mathrm{~K} / 8 \mathrm{ka}$ (eastern) as compared to $1-2 \mathrm{~K} / 7 \mathrm{ka}$ for the model, and $1-$ $2 \mathrm{~K} / 8 \mathrm{ka}$ (western) as compared to $1 \mathrm{~K} / 7 \mathrm{ka}$ for the model. SST trends from Calvo et al. (2002) with $2-3 \mathrm{~K} / 8 \mathrm{ka}$ compare better to $1-2 \mathrm{~K} / 7 \mathrm{ka}$ for the model. Marine sites from Kaufman et al. (2004) in the Nordic Seas give SST trends between 2.5 and $6.6 \mathrm{~K} / 8-10 \mathrm{ka}$, based mostly on diatom proxies and also coccoliths ( 1 core). Despite this weak consistency in absolute temperatures, the proxies give east-west differences that vary more (between $\sim 2 \mathrm{~K}$ for present day and $\sim 6-8 \mathrm{~K}$ for the early Holocene (Calvo et al., 2002; Andersen et al., 2004) as compared to the model (2.5-4.5 for present day and $\sim 5 \mathrm{~K}$ for the early Holocene). It is hard to determine the cause of this mismatch, as it can be partly attributed to our model having a too low sensitivity to applied forcings and partly to uncertainties in proxy reconstructions.

The spatial complexity of the HTM is best expressed by estimating delays and spatial timing differences (c.f. Fig. 7; stars indicate core locations of Kaufman et al., 2004). According to Kaufman et al. (2004) the timing of the HTM at the eastern Greenland Shelf ranges between 9 and $5 \mathrm{kaBP}$, translating into a 0 to $4 \mathrm{ka}$ delay relative to $9 \mathrm{kaBP}$. We take $9 \mathrm{kaBP}$ as a reference because our simulations start at this time, enabling us to compare these proxy estimates to our model. At the South Iceland Shelf the timing is between 7 and $6 \mathrm{ka} \mathrm{BP}$ according to Kaufman et al. (2004), whereas the reconstructed timing on the North Iceland Shelf is between 9 and $6 \mathrm{kaBP}$, resulting in delays between 0 and $3 \mathrm{ka}$ and a spatial timing difference of 0 to $2 \mathrm{ka}$ from south to north. Similar results can be obtained from Andersen et al. (2004) for Greenland and Iceland sites; however, for the eastern side the timing delay is $\sim 1 \mathrm{ka}$.

Our model results for OGGIS seem to be in the range of most of these timing differences, except for the spatial difference between the areas north and south of Iceland that is unmatched. We find it reversed.

\section{Conclusions}

We have applied a fully coupled atmosphere-ocean-sea-icevegetation model to study the impact of early Holocene GIS melt on the climate of the Nordic Seas. Our results suggest the following:

1. From our sensitivity experiments we find that GIS melt has a discernible impact on the AMOC strength and facilitates sea ice growth along the EGC and Denmark Strait. August SSTs are up to $3 \mathrm{~K}$ lower near Denmark Strait, overturning is reduced by $2-3 \mathrm{~Sv}$ and the winter sea ice margin expands south of Denmark Strait 
in a simulation with $13 \mathrm{mSv}$ GIS melt as compared to a simulation forced by changes in orbital parameters and greenhouse gas concentrations.

2. GIS melt can explain some of the spatial differences across the Nordic Seas as reconstructed in several proxy records for the early Holocene. Absolute model temperatures do not compare well with absolute reconstructed temperatures at core locations because of the coarse resolution of our model, but the model seems to capture well the spatial difference across the Nordic Seas. Our model was not able to reproduce the warmth in the early Holocene as suggested by diatom reconstructions near the Norwegian Shelf, and agrees better with alkenonederived SSTs.

3. The spatial distribution of the timing of the HTM in the Nordic Seas is better reproduced in a simulation with GIS melt as compared to a simulation without additional GIS influence. We find delays between the eastern and western sides of $\sim 2000 \mathrm{yr}$.

4. We find in our experiments that GIS melt plays an active role in the Nordic Seas environment. The GIS evolution therefore has to be considered in the evolution of the early Holocene climate and future melting scenarios.

In the context of future climate change this study underlines the importance of GIS melt water and its active role in the climate system. Compared to today, in the early Holocene the annual and summer insolation forcing at $65^{\circ} \mathrm{N}$ (i.e. in South Greenland) was 2.4 and $42 \mathrm{~W} \mathrm{~m}^{-2}$, respectively (Berger and Loutre, 1991). This value of $2.4 \mathrm{~W} \mathrm{~m}^{-2}$ is close to the lower range of the annual radiative forcing of proposed future anthropogenic emission scenarios that varies between 3 and $8.5 \mathrm{~W} \mathrm{~m}^{-2}$ (Meinshausen et al., 2011). Therefore it is not surprising that recently Rignot et al. (2011) reported an acceleration of GIS melt rates that could soon exceed those of the early Holocene, thereby stressing the importance of GIS melt for Nordic Seas future climate evolution.

Acknowledgements. Both M. Blaschek and H. Renssen were supported by funding of the European Community's 7th Framework Program (FP7 2007/2013), Marie-Curie Actions, under grant agreement no. 238111, "CASE ITN", and H. Renssen acknowledges also funding under grant agreement no. 243908, "Past4Future. Climate change - Learning from the past climate". This is Past4Future contribution no. 54. This support is gratefully acknowledged.

Edited by: U. Mikolajewicz

\section{References}

Andersen, C., Koç, N., Jennings, A., and Andrews, J. T.: Nonuniform response of the major surface currents in the Nordic Seas to insolation forcing: Implications for the Holocene climate variability, Paleoceanography, 19, PA2003, doi:10.1029/2002PA000873, 2004.

Andersson, C., Pausata, F. S. R., Jansen, E., Risebrobakken, B., and Telford, R. J.: Holocene trends in the foraminifer record from the Norwegian Sea and the North Atlantic Ocean, Clim. Past, 6, 179-193, doi:10.5194/cp-6-179-2010, 2010.

Bakker, P., Van Meerbeeck, C. J., and Renssen, H.: Sensitivity of the North Atlantic climate to Greenland Ice Sheet melting during the Last Interglacial, Clim. Past, 8, 995-1009, doi:10.5194/cp-8995-2012, 2012.

Berger, A. and Loutre, M.: Insolation values for the climate of the last 10 million years, Quaternary Sci. Rev., 10, 297-317, doi:10.1016/0277-3791(91)90033-Q, 1991.

Brovkin, V., Bendtsen, J., Claussen, M., Ganopolski, A., Kubatzki, C., Petoukhov, V., and Andreev, A.: Carbon cycle, vegetation, and climate dynamics in the Holocene: Experiments with the CLIMBER-2 model, Global Biogeochem. Cy., 16, 86-1-86-20, doi:10.1029/2001GB001662, 2002.

Calvo, E., Grimalt, J., and Jansen, E.: High resolution U37K sea surface temperature reconstruction in the Norwegian Sea during the Holocene, Quaternary Sci. Rev., 21, 1385-1394, doi:10.1016/S0277-3791(01)00096-8, 2002.

Cortese, G., Dolven, J. K., Bjørklund, K. R., and Malmgren, B. A.: Late Pleistocene-Holocene radiolarian paleotemperatures in the Norwegian Sea based on artificial neural networks, Palaeogeogr. Palaeocli., 224, 311-332, doi:10.1016/j.palaeo.2005.04.015, 2005.

Dickson, R., Rudels, B., Dye, S., Karcher, M., Meincke, J., and Yashayaev, I.: Current estimates of freshwater flux through Arctic and subarctic seas, Prog. Oceanogr., 73, 210-230, doi:10.1016/j.pocean.2006.12.003, 2007.

Dolven, J. K., Cortese, G., and Bjørklund, K. R.: A highresolution radiolarian-derived paleotemperature record for the Late Pleistocene-Holocene in the Norwegian Sea, Paleoceanography, 17, 24-1-24-13, doi:10.1029/2002PA000780, 2002.

Driesschaert, E., Fichefet, T., Goosse, H., Huybrechts, P., Janssens, I., Mouchet, A., Munhoven, G., Brovkin, V., and Weber, S. L.: Modeling the influence of Greenland ice sheet melting on the Atlantic meridional overturning circulation during the next millennia, Geophys. Res. Lett., 34, L10707, doi:10.1029/2007GL029516, 2007.

Fichefet, T. and Maqueda, M. A. M.: Sensitivity of a global sea ice model to the treatment of ice thermodynamics and dynamics, J. Geophys. Res., 102, 12609-12646, doi:10.1029/97JC00480, 1997.

Fichefet, T. and Maqueda, M. A. M.: Modelling the influence of snow accumulation and snow-ice formation on the seasonal cycle of the Antarctic sea-ice cover, Clim. Dynam., 15, 251-268, doi:10.1007/s003820050280, 1999.

Funder, S., Kjeldsen, K. K., Kjær, K. H., and Ó Cofaigh, C.: Chapter 50 - The Greenland Ice Sheet During the Past 300,000 Years: A Review, in: Quaternary Glaciations - Extent and Chronology A Closer Look, edited by: Jürgen Ehlers, P. L. G. and Hughes, P. D., 15, 699-713, Elsevier, doi:10.1016/B978-0-444-53447-7.000507, 2011. 
Goosse, H. and Fichefet, T.: Importance of ice-ocean interactions for the global ocean circulation: A model study, J. Geophys. Res., 104, 23337-23355, doi:10.1029/1999JC900215, 1999.

Goosse, H., Driesschaert, E., Fichefet, T., and Loutre, M.-F.: Information on the early Holocene climate constrains the summer sea ice projections for the 21 st century, Clim. Past, 3, 683-692, doi:10.5194/cp-3-683-2007, 2007.

Goosse, H., Brovkin, V., Fichefet, T., Haarsma, R., Huybrechts, P., Jongma, J., Mouchet, A., Selten, F., Barriat, P.-Y., Campin, J.M., Deleersnijder, E., Driesschaert, E., Goelzer, H., Janssens, I., Loutre, M.-F., Morales Maqueda, M. A., Opsteegh, T., Mathieu, P.-P., Munhoven, G., Pettersson, E. J., Renssen, H., Roche, D. M., Schaeffer, M., Tartinville, B., Timmermann, A., and Weber, S. L.: Description of the Earth system model of intermediate complexity LOVECLIM version 1.2, Geosci. Model Dev., 3, 603-633, doi:10.5194/gmd-3-603-2010, 2010.

Hillaire-Marcel, C., de Vernal, A., Bilodeau, G., and Weaver, A. J.: Absence of deep-water formation in the Labrador Sea during the last interglacial period, Nature, 410, 1073-1077, doi:10.1038/35074059, 2001.

Hillaire-Marcel, C., de Vernal, A., and Piper, D. J. W.: Lake Agassiz Final drainage event in the northwest North Atlantic, Geophys. Res. Lett., 34, L15601, doi:10.1029/2007GL030396, 2007.

IPCC: Climate Change: The Scientific Basis, Chap. 6, 349-416, Cambridge University Press, Cambridge, UK and New York, NY, USA, 2001.

Jansen, E., Overpeck, J., Briffa, K., Duplessy, J.-C., Joos, F., Masson-Delmotte, V., Olago, D., Otto-Bliesner, B., Peltier, W., Rahmstorf, S., Ramesh, R., Raynaud, D., Rind, D., Solomina, O., Villalba, R., and Zhang, D.: Palaeoclimate, in: Climate Change 2007: The Physical Science Basis, available at: http://www.ipcc. ch/publications_and_data/ar4/wg1/en/ch6.html, 2007.

Jansen, E., Andersson, C., Moros, M., Nisancioglu, K. H., Nyland, B. F., and Telford, R. J.: The Early to Mid-Holocene Thermal Optimum in the North Atlantic, Wiley Blackwell, 123-137, doi:10.1002/9781444300932.ch5, 2008.

Kanzow, T., Cunningham, S. A., Johns, W. E., Hirschi, J. J.M., Marotzke, J., Baringer, M. O., Meinen, C. S., Chidichimo, M. P., Atkinson, C., Beal, L. M., Bryden, H. L., and Collins, J.: Seasonal Variability of the Atlantic Meridional Overturning Circulation at $26.5^{\circ} \mathrm{N}$, J. Climate, 23, 5678-5698, doi:10.1175/2010JCLI3389.1, 2010.

Kaplan, M. R. and Wolfe, A. P.: Spatial and temporal variability of Holocene temperature in the North Atlantic region, Quaternary Res., 65, 223-231, doi:10.1016/j.yqres.2005.08.020, 2006.

Kaufman, D., Ager, T., Anderson, N., Anderson, P., Andrews, J., Bartlein, P., Brubaker, L., Coats, L., Cwynar, L., Duvall, M., Dyke, A., Edwards, M., Eisner, W., Gajewski, K., Geirsdóttir, A., Hu, F., Jennings, A., Kaplan, M., Kerwin, M., Lozhkin, A., MacDonald, G., Miller, G., Mock, C., Oswald, W., Otto-Bliesner, B., Porinchu, D., Rühland, K., Smol, J., Steig, E., and Wolfe, B.: Holocene thermal maximum in the western Arctic (0-180 ${ }^{\circ}$ W), Quaternary Sci. Rev., 23, 529-560, doi:10.1016/j.quascirev.2003.09.007, 2004.

Kleinen, T., Osborn, T., and Briffa, K.: Sensitivity of climate response to variations in freshwater hosing location, Ocean Dynam., 59, 509-521, doi:10.1007/s10236-009-0189-2, 2009.
Koç, N., Jansen, E., and Haflidason, H.: Paleoceanographic reconstructions of surface ocean conditions in the Greenland, Iceland and Norwegian seas through the last $14 \mathrm{ka}$ based on diatoms, Quaternary Sci. Rev., 12, 115-140, doi:10.1016/02773791(93)90012-B, 1993.

Licciardi, J. M., Teller, J. T., and Clark, P. U.: Freshwater routing by the Laurentide Ice Sheet during the last deglaciation, AGU Geophysical Monograph, 112, 177-201, 1999.

MARGO Project Members, Waelbroeck, C., Paul, A., Kucera, M., Rosell-Melé, A., Weinelt, M., Schneider, R., Mix, A. C., Abelmann, A., Armand, L., Bard, E., Barker, S., Barrows, T. T., Benway, H., Cacho, I., Chen, M.-T., Cortijo, E., Crosta, X., de Vernal, A., Dokken, T., Duprat, J., Elderfield, H., Eynaud, F., Gersonde, R., Hayes, A., Henry, M., Hillaire-Marcel, C., Huang, C.C., Jansen, E., Juggins, S., Kallel, N., Kiefer, T., Kienast, M., Labeyrie, L., Leclaire, H., Londeix, L., Mangin, S., Matthiessen, J., Marret, F., Meland, M., Morey, A. E., Mulitza, S., Pflaumann, U., Pisias, N. G., Radi, T., Rochon, A., Rohling, E. J., Sbaffi, L., Schäfer-Neth, C., Solignac, S., Spero, H., Tachikawa, K., and Turon, J.-L.: Constraints on the magnitude and patterns of ocean cooling at the Last Glacial Maximum, Nat. Geosci., 2, 127-132, doi:10.1038/ngeo411, 2009.

Meinshausen, M., Smith, S., Calvin, K., Daniel, J., Kainuma, M., Lamarque, J.-F., Matsumoto, K., Montzka, S., Raper, S., Riahi, K., Thomson, A., Velders, G., and van Vuuren, D.: The RCP greenhouse gas concentrations and their extensions from 1765 to 2300, Clim. Change, 109, 213-241, doi:10.1007/s10584-0110156-z, 2011.

Opsteegh, J. D., Haarsma, R. J., Selten, F. M., and Kattenberg, A.: ECBILT: a dynamic alternative to mixed boundary conditions in ocean models, Tellus A, 50, 348-367, doi:10.1034/j.16000870.1998.t01-1-00007.x, 1998.

Peltier, W.: Global Glacial Isostasy And The Surface Of The Ice-age Earth: The ICE-5G (VM2) Model And Grace, Annu. Rev. Earth Planet. Sci., 32, 111-149, doi:10.1146/annurev.earth.32.082503.144359, 2004.

Renssen, H., Goosse, H., Fichefet, T., Brovkin, V., Driesschaert, E., and Wolk, F.: Simulating the Holocene climate evolution at northern high latitudes using a coupled atmospheresea ice-ocean-vegetation model, Clim. Dynam., 24, 23-43, doi:10.1007/s00382-004-0485-y, 2005.

Renssen, H., Goosse, H., and Muscheler, R.: Coupled climate model simulation of Holocene cooling events: oceanic feedback amplifies solar forcing, Clim. Past, 2, 79-90, doi:10.5194/cp-2-792006, 2006.

Renssen, H., Seppa, H., Heiri, O., Roche, D. M., Goosse, H., and Fichefet, T.: The spatial and temporal complexity of the Holocene thermal maximum, Nat. Geosci, 2, 411-414, doi:10.1038/ngeo513, 2009.

Renssen, H., Goosse, H., Crosta, X., and Roche, D. M.: Early Holocene Laurentide Ice Sheet deglaciation causes cooling in the high-latitude Southern Hemisphere through oceanic teleconnection, Paleoceanography, 25, PA3204, doi:10.1029/2009PA001854, 2010.

Rignot, E., Velicogna, I., van den Broeke, M. R., Monaghan, A., and Lenaerts, J.: Acceleration of the contribution of the Greenland and Antarctic ice sheets to sea level rise, Geophys. Res. Lett., 38, L05503, doi:10.1029/2011GL046583, 2011. 
Risebrobakken, B., Jansen, E., Andersson, C., Mjelde, E., and Hevrøy, K.: A high-resolution study of Holocene paleoclimatic and paleoceanographic changes in the Nordic Seas, Paleoceanography, 18, 1017, doi:10.1029/2002PA000764, 2003.

Risebrobakken, B., Dokken, T., Smedsrud, L. H., Andersson, C., Jansen, E., Moros, M., and Ivanova, E. V.: Early Holocene temperature variability in the Nordic Seas: The role of oceanic heat advection versus changes in orbital forcing, Paleoceanography, 26, PA4206, doi:10.1029/2011PA002117, 2011.

Schmittner, A., Latif, M., and Schneider, B.: Model projections of the North Atlantic thermohaline circulation for the 21st century assessed by observations, Geophys. Res. Lett., 32, L23710, doi:10.1029/2005GL024368, 2005.

Schrama, E. J. O. and Wouters, B.: Revisiting Greenland ice sheet mass loss observed by GRACE, J. Geophys. Res., 116, B02407, doi:10.1029/2009JB006847, 2011.

Siddall, M., Rohling, E. J., Almogi-Labin, A., Hemleben, C., Meischner, D., Schmelzer, I., and Smeed, D. A.: Sea-level fluctuations during the last glacial cycle, Nature, 423, 853-858, doi:10.1038/nature01690, 2003.

Simpson, M. J., Milne, G. A., Huybrechts, P., and Long, A. J.: Calibrating a glaciological model of the Greenland ice sheet from the Last Glacial Maximum to present-day using field observations of relative sea level and ice extent, Quaternary Sci. Rev., 28, 16311657, doi:10.1016/j.quascirev.2009.03.004, 2009.

Smith, T. M., Reynolds, R. W., Peterson, T. C., and Lawrimore, J.: Improvements to NOAA's Historical Merged Land-Ocean Surface Temperature Analysis (1880-2006), J. Climate, 21, 22832296, doi:10.1175/2007JCLI2100.1, 2008.
Stouffer, R. J., Yin, J., Gregory, J. M., Dixon, K. W., Spelman, M. J., Hurlin, W., Weaver, A. J., Eby, M., Flato, G. M., Hasumi, H., $\mathrm{Hu}$, A., Jungclaus, J. H., Kamenkovich, I. V., Levermann, A., Montoya, M., Murakami, S., Nawrath, S., Oka, A., Peltier, W. R., Robitaille, D. Y., Sokolov, A., Vettoretti, G., and Weber, S. L.: Investigating the Causes of the Response of the Thermohaline Circulation to Past and Future Climate Changes, J. Climate, 19, 1365-1387, doi:10.1175/JCLI3689.1, 2006.

Swingedouw, D., Rodehacke, C., Behrens, E., Menary, M., Olsen, S., Gao, Y., Mikolajewicz, U., Mignot, J., and Biastoch, A.: Decadal fingerprints of freshwater discharge around Greenland in a multi-model ensemble, Clim. Dynam., doi:10.1007/s00382012-1479-9, in press, 2012.

Vinther, B. M., Buchardt, S. L., Clausen, H. B., Dahl-Jensen, D., Johnsen, S. J., Fisher, D. A., Koerner, R. M., Raynaud, D., Lipenkov, V., Andersen, K. K., Blunier, T., Rasmussen, S. O., Steffensen, J. P., and Svensson, A. M.: Holocene thinning of the Greenland ice sheet, Nature, 461, 385-388, doi:10.1038/nature08355, 2009.

Wiersma, A. and Renssen, H.: Model-data comparison for the $8.2 \mathrm{ka}$ BP event: confirmation of a forcing mechanism by catastrophic drainage of Laurentide Lakes, Quaternary Sci. Rev., 25, 63-88, doi:10.1016/j.quascirev.2005.07.009, 2006. 